\title{
La ponctuation dans Ce que j'appelle oubli de Laurent Mauvignier: enjeux et paradoxe
}

Préparé par:

Dr. Ekram Hassan Alanwar Hussein

Under the Supervision of

Professor Bahaa M. Mazid

$\&$

Doctor Hanan Abualtaher Ebaid

English Department

Faculty of Arts

Sohag University 



\section{Abstract}

The children's literature translation studies (CLTS) is an evolving discipline, particularly in the Arab world. Christiane Nord's translation-oriented text analysis follows a long tradition of the functional theory including Katharina Reiss's text type approach, Mary Snell-Hornby's integrated approach, Holz-Mänttäri's translatorial action, and most importantly, Hans J. Vermeer's Skopos theory. This paper applies Christiane Nord's translation-oriented text analysis (2005) to AbdutTawaab Youssef 's translated story: الناي الحزين The Magic Flute in order to present a better translation. AbdutTawaab Youssef is one of the pioneer writers of children's literature in the Arab world. Youssef wrote all his stories, including this story, to be read by Arabic-speaking children. The story is translated by Dr. Loubna Youssef, the author's daughter, to be read by English-speaking children. By analyzing the source text (ST) following Nord's model, some translation problems may arise. Accordingly, suggested solutions are introduced to yield a better translation of the target text (TT). Importantly, it is the effect of the better translation on TT child reader that should be taken into consideration.

Keywords: children's literature translation studies, functional theory. 
The Application of Christiane Nord's Translation-

Oriented Text Analysis to AbdutTawaab Youssef's

Translated Story الناي الحزين The Magic Flute

Many theories have been applied to the translation of children's literature. They approached it from different perspectives. Yet, they did not provide systematic analysis of elements of ST. This paper applies Christiane Nord's translation-oriented text analysis to the translated Arabic children's story الناي الحزيين The Magic Flute with the aim of suggesting better translations to the translation problems that may arise.

\section{Literature Review}

Riitta Oittinen introduced the Russian philosopher Mikhail Bakhatin's idea of dialogism as one of the approaches of translating children's literature. Bakhatin regards the reading experience as a dialogic, give-and-take process consisting of different writers, readers, and contexts as well as the past, present and future (as cited in Coillie \& Verschueren, 2006, p. 37). Moreover, Oittinen explained Bakhatin's carnivalism as some kind of ritual act, which he calls 'the mock crowning and subsequent uncrowning of the king/queen' (original emphasis). He sees translation in many ways as a kind of carnivalistic action: crowning and uncrowning. Bakhtin argues that, today, the author is the king/queen, tomorrow s/he is uncrowned and the translator becomes the king/queen, then the translator loses his/her crown and the target language reader receives 'the symbols of authority'. It is a never-ending process (as cited in Lathey, 2006, pp. 84/96-97).

Tiina Puurtinen maintained that Gideon Toury advocated a descriptive target-oriented approach to literary translation which is a contradistinction to text-oriented 
theories of translation. Toury regards translations as textuallinguistic products which belong to the target literary system. Every translation occupies a position on a continuum between two poles, adequacy and acceptability. According to Toury, the translator who aims at an adequate translation follows the norms of the source language and the source literary polysystem. On the other hand, in order for the translation to be acceptable, the translator will observe the linguistic and literary norms of the target system (or as in the case of children's literature translation) genre or subgenre. He sees the relationship between an ST and its translation as equivalent, yet it is the task of the descriptive translation studies to establish what kind of equivalence exists.

Puurtinen applied this concept to children's literature explaining that in the translation of children's books, translational norms tend to place the target text close to the acceptability pole. Puurtinen gives the example of the Finnish translations of The Wizard of $\mathrm{Oz}$ and how they are expected to observe the linguistic and literary norms that are dominant in contemporary Finnish children's literature. Puurtinen sees that the preference of acceptability is concerned with the characteristics of the target group: children. Their imperfect reading abilities and experience of life make them unable to understand many alien and strange elements as adult readers, in addition to the peripheral position of translated children's literature, which makes any translator rely on what is 'conventionalized' in the target system (as cited in Lathey, 2006, pp. 54-57).

In the same vein, Zohar Shavit (1981, pp. 171- 177) in her article: Translation of Children's Literature as a Function of its Position in the Literary Polysystem contended that the behavior of the translations of children's literature is determined by the position of the children's literature system 
in the literary polysystem, based on Even-Zohar polysystem theory (1978a). She argues that, at the beginning, children's literature was not one whole system, it was stratified into two main systems: canonized and non-canonized.

Accordingly, Shavit stresses the concept of systematic affiliation. The systemic affiliation of a text which enters children's system is similar to the case of a text which enters the non-canonized system for adults. This similarity between the systems can be the reason for the same constraints which work on the two systems. According to Shavit, the systemic affiliation is manifested by four elements: affiliation to existing models, the integrality of the text's primary and secondary models, the degree of complexity and sophistication of the text, its adjustment to ideological and didactic purposes and the style of the text.

Shavit concluded that children's literature reveals behavior patterns which belonged in previous stages to adult literature. Even when the same pattern is common to both, the reasons for it can be different, and they can express the different concepts of the two literatures and their different self-images.

Puurtinen introduced the Swedish scholar Göte Klingberg's view of the translation of children's literature. Klingberg assumes that the author of the original work has to take into account the interests of the child reader as well as his/her reading ability, and has to make the text suitable to $\mathrm{him} / \mathrm{her}$. This is what Klingberg calls 'the degree of adaptation of the source text', which he regards as what should be preserved in translation. Puurtinen referred to Klingberg's studies about the translations of some Swedish children's books into English and vice versa, where he focused on investigating whether the translators have succeeded in maintaining the original degree of adaptation. 
Klingberg seems to be a great supporter of adequacy instead of acceptability. Unfortunately, he made no reference to the possibly different norms and conventions of the source and target systems of children's literature, which would require different levels of linguistic (and cultural) difficulty. Puurtinen concludes by asserting that "faithfulness to the original is Klingberg's main guideline" (as cited in Lathey, 2006, pp. 59-60).

In opposition to Klingberg's viewpoint, Gillian Lathey (2006, p. 7) maintained that Klingberg's adaptation or 'cultural context adaptation' has been used as an umbrella term for many strategies to move the original text towards the child reader in the target culture. According to Lathey, adaptation rests on the assumptions that young readers might find it difficult to assimilate foreign names, foods or locations that may lead them to reject a text reflecting a culture that is unfamiliar to them.

Mieke K.T. Desmet investigated intertextuality in translating children's books. Desmet referred to Maria Nikolajeva's concept that all forms of discourse whether intended for adults or children derive their significance from relationships to texts that precede them and texts that follow them. Accordingly, Desmet suggests two main strategies for translating a text which is highly intertextual. On the one hand, there is a translation strategy that would translate all the references in the text literally. That is choosing the closest equivalent in the target language. On the other hand, a different approach may be applied by using substitutions that work in the target culture and create a similar effect in the target reader. Desmet introduces the Jolly Postman books (1989-1997) as an example of a highly intertextual texts and how they were translated into Dutch. They are three books about a postman delivering letters, these letters are 
interleaved between the pages of the books in open envelopes for exploration by the readers. The Dutch translator, Ernest Van Altena, had to strike some balance between rendering the British local Colour of the source text and positioning the target texts in the target Dutch literary culture by combining straightforward translation with substitution, compensation (or addition) and deletion strategies. The relationship between the illustrations and the verbal text is crucial as these illustrations can provide a kind of intertextual links that are not mentioned in the text itself (as cited in Lathey, 2006, pp. 122-127).

In view of what referred to earlier, none of the different approaches that tackled the translation of children's literature has provided a systematic approach to the translation of children's literature. Munday (2008, pp. 82-84) referred to Christiane Nord's Text Analysis in Translation (1998/2005) as a more detailed functional model that incorporate elements of text analysis that examines text organization at or above sentence level. He regards Nord's model as a synthesized approach that brings together the strengths of the various functional theories. Accordingly, Christiane Nord's translation-oriented text analysis will be the theoretical framework of this paper.

\section{Discussion}

\section{Nord's Theory}

The translation-oriented text analysis model introduced by Christiane Nord relies heavily on the functional concept. It introduces a model of ST analysis that would enable translators to understand the function of the elements in the ST. In the light of this function, they can select the suitable translation strategies suitable for the intended purpose of the translation (Nord, 2005, Introduction). The factors of ST 
analysis are: the extratextual factors, the intratextual factors and the effect.

The Extratextual factors. They include: sender, sender's intention, audience (receivers), medium, place of communication, time of communication, motive for communication and text function.

The Intratextual factors. They encompass: subject matter, content, presuppositions, text composition, nonverbal elements, lexis, sentence structure, and suprasegmental features.

The effect. It can be determined by both the extratextual factors, and the intratextual factors as well as the relationship between intention and text, the relationship between receiver and text world, and the relationship between receiver and style.

The following is a detailed analysis of the story of الناي الحزين The Magic Flute following Nord's model. It is important to stress the recursive and circular approach of this model.

The extratextual factors. On analyzing the extratextual factors following Nord's approach, some translation problems will arise. Thereby, there will be suggested solutions to these problems.

The story sender. The sender of the story is AbdutTawaab Youssef (1928-2015) as indicated in the cover page of the story. Unfortunately, there is no reference to the biography of the story writer in the text environment.

Translation problem (1). As a matter of fact, Youssef is one of the key figures of the children's literature in the whole Arab region, and a well-known figure to children in Egypt. Yet, the TT receiver i.e. the English-speaking child reader does not have a similar background knowledge about the author of the story. This causes a problem related to translation. 
Suggested solution. It is suggested to add the biography of the author in the text environment: at the back of the title page or at the end of the story or at the back of the back cover with a photo of the author.

The sender's intention. On the left of the title page, there is this statement written in English: Try to read this book from right to left for the first time in your life.

Translation problem (2). It is highly likely that this statement is directed to the non-Arab children who are asked to: Try to read this book from right to left for the first time in your life. First of all, this text is related to children's literature, it is not a textbook for teaching the Arabic language to the non-Arab children. Second, how could an English-speaking child try to read Arabic for the first time in his/her life, as indicted in the blurb, by merely reading a story written in Arabic? Accordingly, the question to be raised here is: does that statement reveal the sender's intention or the translator's intention or the publishing house policy? This causes a translation problem.

Suggested solution. It is likely that this statement is added by the translator with the approval of the publishing house to attract the attention of the English-speaking child reader to try a new, though controversial, experience: reading this book from right to left for the first time in his/her life. However, as long as the focus of this paper is on the story of لناي الحزين land its translated text, it is suggested to overlook this statement.

The receiver. In view of what is referred to in the sender's part and the sender's intention, it follows that this story is originally written in Arabic by an Arab children's writer. However, as the ST is put side by side with the TT, this story can be read from right to left "as expected" by the 
Arab children and from left to right by the English-speaking children. Accordingly, this story can be directed to both the Arab children who read the original Arabic text and the nonArab child reader who will receive the English text. As a result, children will be divided into two categories of story receivers according to which text will be read first: the Arabic text or the English text.

Translation problem (3). The different linguistic and cultural backgrounds of each category of receivers make it not easy to consider the text from only one perspective. From the Arab readers' perspective, the ST is the Arabic text and the English text will be the translation while for the non-Arab readers the ST will be the English text and the Arabic text will be the translation. The duality of the receivers of each text poses a translation problem.

Suggested solution. It is suggested to regard the Arabic text as the ST that is directed to the Arab child reader and the English text as the TT that is directed to the English-speaking child reader and condone any extra assignments given to any of the two texts.

Moreover, the age of the ST receivers is a matter of interest here. Which age category of the Arab children does the story address? Unfortunately, the concept of age category is not common in the industry of children's books in the Arab world so far. A story written for children is expected to be read by children at any age from zero to 18 years old. This attitude may be attributed to commercial reasons. There is a need for more investigation in this respect, which is beyond the scope of this paper.

The Medium. This story is presented in medium size with paper cover. As referred to earlier in the receiver's part, the Arabic text and its translation are presented in the same volume. 
Translation problem (4). It follows that the Arab child reader may be distracted by reading the Arabic origin then the English translation in case that he/she knows both languages and that $\mathrm{s} / \mathrm{he}$ is interested to follow the incidents in Arabic and English. S/he may wonder whether it is an Arabic story translated into English or an English story rendered into Arabic.

Suggested solution. It is suggested to separate the Arabic ST from the English TT yet keep both in one volume. The Arabic text will be presented by opening the book from right to left and the English text from left to right with the same illustrations accompanying both texts. In this case the number of pages as well as illustrations will be doubled. This solution may cause some financial problems to the publishing house. However, the separation of the two texts can give the publishing house the opportunity to address both receivers separately. It is supposed that it is a way of compensating for the more costs and may be regarded as an endeavor for opening new market abroad.

The place of communication. On the front cover, there is a reference to the publishing house of the story. It is published by The Egyptian General Book Authority in Cairo. It is an Arabic children's story written by Egyptian children's author and published by public publishing house in Egypt to be introduced to the Arab child reader.

The time of communication. There is no indication of the time of publishing this story. However, the deposit number refers to 1995. Surely, this date is after the date of the publication and the translation of this story. It is probable that there is no time lag between publishing ST and publishing the TT, bearing in mind that they are presented in the same volume. 
The motive for communication. In view of what is referred to in the sender's part, and the receiver's part, the story is written by AbdutTawaab Youssef, the motive for writing الناي الحزين The Magic Flute is the same as it is for all Youssef's stories: to entertain and educate the Arab child reader. Accordingly, the motive for the translation of this Arabic children's story is to entertain and educate the English-speaking child reader.

\section{Text function.}

[L]iterariness ... is a pragmatic quality which is assigned to certain texts by the sender and the receiver in a particular communicative situation.

(Nord, 2005, p. 79)

In view of what is referred to earlier in the sender's intention and the motive for the text, this text is basically a children's story written in Arabic. So, the ST is a literary text that is translated into another literary text in TC. It is not a textbook for teaching the non-Arab children the Arabic language.

Translation problem (5). It is clear that the pedagogical approach in Arabic children's literature that has dominating the scene for decades is still manifested in Youssef's stories. However, by adding another function to it, the text may be drifted away from its main function. This represents a translation problem.

Suggested solution. As referred to earlier, it is suggested to focus on the main function of the story as a literary text and ignore any extra function.

The interdependence of extratextual factors. After reviewing the extratextual factors of this text, it seems that these factors have collaborated to make the communicative situation of the story clearly presented. Nord (2005) puts it 
that way, "the meaning of a text can be elicited ... "through the filter" of extratextual knowledge" (p. 99, original emphasis). Importantly, the recursive approach of Nord's model gives way to reconsider every extratextual element in the light of the data provided in the other elements. Accordingly, the child reader will have some predictions or otherwise expectations concerning what this story will be about. However, the analysis of intratextual factors of this text will either confirm or contradict these expectations.

There is one element that it is suggested to be added to the extratextual factors. It is the lay out of the story. It is actually an element that is essentially existed in all stories, yet it is highly recommended in the analysis of this story. As the setting of the story is the pharaonic environment, this exquisite format and the whole layout of the story gives an atmosphere that help prepare the child reader to receiver the incidents of the story.

Intratextual factors. Through the analysis of the intratextual factors, following Nord's model, some translation problems will arise. Therefore, there will be suggested solutions to these problems.

Subject matter. The story is a thematically coherent single text. الناي الحزين The Magic Flute is a fairytale about a young pharaonic shepherd called Iye Tue and his amazing flute. The flute is a cultural marker of the Egyptian environment. It's a popular musical instrument made of common reed. It has this connection to sad tunes in the Egyptian collective mind.

Translation problem (6). Importantly, the title of the story is الناي :الناي الحزيين the flute is described by the author as being sad الحزين. However, the translator, who is the author's daughter, has chosen to translate it, instead, as The Magic 
Flute. In addition to changing the meaning intended by the author that has cultural connotation, this translation has unfolded an aspect of the story that would better be revealed while reading the incidents. She, thus, has deprived the story of one of its major characteristics: mystery. This poses a translation problem.

Suggested solution. It is suggested to translate الناي الحزيين as The Sad Flute.

Content. Paraphrasing the story. The story is about Iye Tue, the young Egyptian shepherd who used to graze next to the banks of the Nile very close to the palace of princess Namio. Iye Tue cannot talk that's why he feels that he cannot make friends with the princess whom he cherishes. He used to hide from her sight behind the trees. One day, he met the Mermaid of the Nile who was sent by the moon to help him. She gave him one of sticks of the common reed. She asked him to blow into one of its sides. When he couldn't hear any tunes, he felt sad and his tears fell on the stalk making seven holes in it. When he began to blow fiddling with theses holes, beautiful tunes came out of them filling the whole world. The princess could hear the music. That's why she came to him, asking him to continue playing these amazing tunes and thus they became friends.

The Internal situation. The sender. The sender is a third person narrator.

The receiver. The receivers of the story may be the children at the time of the story who lived in ancient Egypt on banks of the Nile River along with their family members.

The time and place. The time of the story is the Pharaonic era as indicated in the clothing and names of the main characters. The place is ancient Egypt at the banks of the Nile River. 
The medium. The story is presented in a narrative form.

The motive. The motive is to tell the story of the first flute ever known to the world. It was the hot tears of the little Egyptian shepherd that had given all humanity that amazing musical instrument as the author declares at the end of the story:

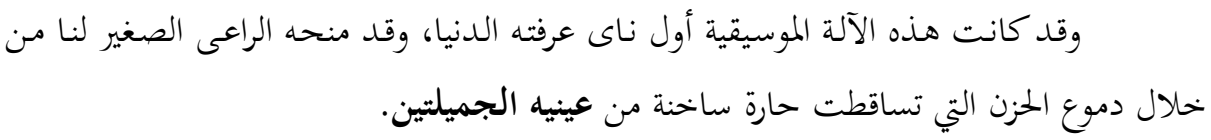

This sentence was rendered into English as follows: This musical instrument is the first flute known to the world. This is the gift of the young shepherd to man, one that his sad warm tears produced.

Translation problem (7). The translator did not render this phrase of عينيه الجميلتين his beautiful eyes into English. In this concluding statement, the author introduced an image where the warm tears of Iye Tue are mixed with the beauty of his eyes to present to the world the first flute ever. This meaning was not introduced in full by the translator. This constitutes a translation problem.

Suggested solution. It is suggested to translate the above-mentioned statement as follows: This is the gift of the young shepherd to man, one that his beautiful eyes with their sad warm tears have produced.

The function. It is a story for children, presented to entertain and amuse them.

Presuppositions. Nord (2005, pp. 105-110) assumes that presuppositions include the information that the sender presupposes that the receiver has, i.e. it is expected to be part of his/her horizon. As a result, the sender has to consider the communicative situation, the general background knowledge of the receiver, and the relevance of the information to be 
transmitted in order to decide which presuppositions to be made and which are not. This situation applies to the translator as well. S/he has to bear in mind that the information that may seem trivial to the source culture receiver because of his/her background knowledge as an SC addressee, may be unknown to the TC receiver because of his/her background knowledge, and thus has to be mentioned in the text.

Translation problem (8). In view of what is referred to in the subject matter as well as the content, this text is a fairytale about a young pharaonic shepherd and his amazing flute. However, Arab children can have background knowledge about the Ancient Egyptian civilization whereas the English-speaking child reader may have little or no idea about the pharaonic civilization, the Nile River, the Mermaid of the Nile, or the common reed that the flute of is made of. This constitutes a translation problem.

Suggested solution. It is suggested to give more information about the cultural markers of this story such as the Nile, common reed, the Mermaid of the Nile. This information may be presented either in parentheses or in footnotes. This will be shown in more detail in the text composition and lexis parts in this paper.

Text composition. Text ranks. As the ST is an independent text that belongs to the genre of fairytale. It has the basic structure of a fairytale with the exception of the existence of the villains. The author presented: the hero (Iye Tue), the helping friend or otherwise the helping tool (the flute) and the magical creature (the Mermaid of the Nile), a problem to be solved (making friends with the princess Namio), the moral message and finally the happy ending (becoming a friend of the princess).

Macrostructure. The story is introduced in 32 pages. It 
begins with the beauty of the natural landscape on the Nile River banks with the young shepherd Iye Tue grazing nearby. It ends with the invention of the first flute ever known to the world. The ST is presented by one paragraph at the bottom of the right page with its English translation facing it on the same page. The only exception is on pages (10) and (32) where there is more than one paragraph. The left page is allocated for the illustrations that follows the written text, step by step. Unfortunately, the translator has made some modifications to the organization of TT with no specific reasons.

Translation problem (9). The TT precedes the ST in the following extract:

Please, don't talk and don't thank me for what I say. (p.30)

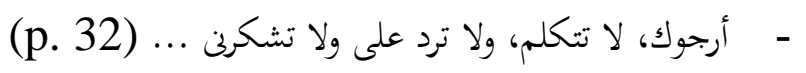

The author ended page (30) with the princess praising the tunes that Iye Tue has played. Then he started page (32) with the princess asking him not to talk and to have some rest after playing the flute. The translator, on the other hand, has preceded the ST in introducing this idea and presented part of it on page 30 . This poses a translation problem.

Suggested solution. It is suggested to cut the abovementioned TT sentence and paste it in its proper place at the beginning of page 32 .

Translation problem (10). Interestingly, on the same page (32), the translator merges the last two paragraphs into one, as indicated in the following extract:

هز الولد رأسه، بفرحة غامرة: أي نعم. ساعتها أختفت عروسة النيل في مياه النهر،

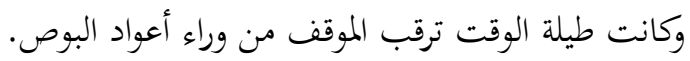


وقد كانت هذه الآلة الموسيقية أول ناى عرفته الدنيا، وقد منحه الراعى الصغير لنا من

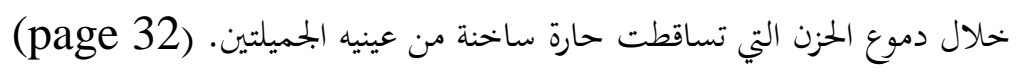

In overwhelming happiness, the young shepherd shakes his head to say "yes". At this instant the Mermaid of the Nile disappears into the waters of the river. She has been watching the scene from behind the stalks on the river bank. This musical instrument is the first flute known to the world. This is the gift of the young shepherd to man, one that his sad warm tears produced.

The author introduced the last incident of his story in the first paragraph then presented the conclusion or the closing paragraph in the next one. This order of incidents is ignored by the translator, which causes a translation problem.

Suggested solution. It is suggested to divide this TT paragraph into two and render it the way it is presented in ST:

In overwhelming happiness, the young shepherd shakes his head to say "yes". At this instant, the Mermaid of the Nile disappears into the water of the river. She has been watching the scene from behind the stalks on the river bank.

This musical instrument is the first flute known to the world. This is the gift of the young shepherd to man, one that his sad warm tears produced.

Translation problem (11). Importantly, the unjustified split of the ST paragraph on page (10) is encountered by similar split in TT, as indicated in the following extract:

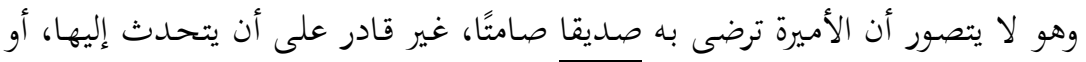

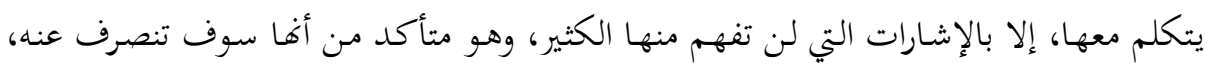

$$
\begin{aligned}
& \text { وتضيق به، }
\end{aligned}
$$

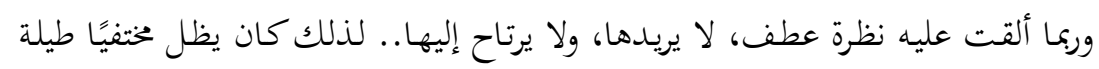

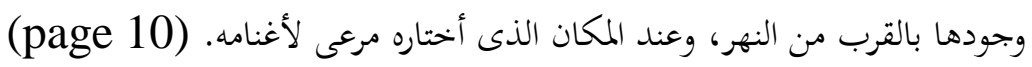


Surely, the princess will not accept a silent friend who will not be able to hear or talk to her. He can only use sign language that she is not familiar with. He is sure she will not enjoy his company or perhaps she may look upon him with pity: a feeling he does not like. This is why he hides whenever she comes near the river, especially when she comes close to the spot he chose for his cattle to graze.

It follows that it could be a misprint in the ST, however, it should not be transferred with equivalent misprint in the TT. It is the translator's duty to compensate for any defects in the ST. This poses a translation problem.

Suggested solution. It is beyond the authority of the translator to change or modify any part of the ST. However, s/he can modify or alter any item of the TT, so it is suggested to rewrite the above-mentioned paragraph in the TT and unite it into one.

Microstructure. In view of what is referred to in the macrostructure part, the translator follows the same pattern at the sentence level: she tended to paraphrase, add, as well as, delete some phrases and clauses while translating the ST. The followings are some examples of the modifications she made to some sentences and the translation problems that have emerged thereby.

Translation problem (12). The translator added phrases that have no equivalence in the ST, as on the supposed to be page (2): "Amidst this charming scene". This phrase acted as her own comment on the beautiful scene described earlier. This poses a translation problem.

Suggested solution. It is suggested to delete this phrase from the TT and stick to what is presented in the ST.

Translation problem (13). The translator neglects translating some phrases as the following phrase on the 
supposed to be page (2): "بين الضفاف السمر". The author describes a scenery of a beautiful day in Egypt, then ends with setting the location where all this beauty exists. By ignoring this phrase, the translator introduces incomplete picture to the TT child reader. In the same vein, the translator did not translate the following clause on page (12):

$$
\text { "ويطل على أغنامه، خشية أن تكون أحداها قد شردت هنا أو هناك ...". }
$$

These two behaviors pose the same translation problem.

Suggested solution. It is suggested to render بين الضفاف ويطل على أغنامه، خشية أن تكون as between the brown banks and السمر as he used to check on his sheep for fear that one of them would have gone here or there.

Translation problem (14). The translator has replaced the following ST clause on page (10): وهو لا يتصور أن الأميرة ترضى به صديقا صامتًا غير قادر على أن يتحدث إليها، أو يتكلم معها، ... by the following TT clause:

Surely, the princess will not accept a silent friend who will not be able to hear or talk to her.

Interestingly, Iye Tue had these thoughts that the princess would not accept him as a friend because he could not talk. The translator had turned these imaginary ideas into reality by starting the clause with "surely". This causes a translation problem.

Suggested solution. It is suggested to translate this clause as follows:

He could not imagine that the princess would take him a mute friend who he could not talk to her ...

In the same vein on page (14), the whole picture of Iye Tue's warm tears that ran down his face, expressing his pain 
and sorrow, is rendered into English as: Warm tears water his face. This poses a translation problem.

$$
\text { وفي كل مرة تتساقط دموعه ساخنة، معبرة عن مدى ألمه وأساه، ... }
$$

Warm tears water his face.

Suggested solution. It is suggested to transfer the exact picture depicted in the ST to the TT as follows: Each time his warm tears run down his face, expressing his pain and sorrow, ...

Translation problem (15). The translator has made unjustified split of the following sentence on page (18): فزع . الراعي الصغير (آى تو) لدى رؤيه عروسه النيل تخرج إليه، ... She rendered it in two sentences in the TT: The young shepherd Iye Tue is shocked to see the Mermaid of the Nile. She comes out to him. This causes a translation problem.

Suggested solution. It is suggested to translate the above-mentioned sentence as follows: The young shepherd Iye Tue was shocked to see the Mermaid of the Nile coming out of the water and heading towards him.

Translation problem (16). The direct speech in the ST on page (20) is transferred into indirect speech:

$$
\text { والقمر يقول لك: إنه من الممكن لك أن تعبر عن نفسك وأن تتحدث بالكثير .... }
$$

The moon tells you that you can communicate your thoughts and feelings .... This causes a translation problem.

Suggested solution. It is suggested to translate this direct speech as follows:

The moon says, "you can communicate your thoughts and feelings...

Translation problem (17). The translator edited the following image, depicted by the author on page (26), ولم يعد في الوجود مخلوق إلا وهو يستمع إليها مسحورا بها. following: The music is truly enchanting. 
Suggested solution. It is suggested to the abovementioned sentence as follows: There was not a single soul in this universe that was not enchanted by that music.

Non-verbal elements. Illustrations. They are conventionally connected to children's stories. The illustrator is Fatma Darwish. Darwish has presented the illustrations in colour. As referred to earlier in the medium part, both the ST and TT are presented in the same volume and on the same page with the illustrations facing them on the other page. By so doing, the publishing house may have an intention, in addition to cutting the cost of paying for a new volume, of achieving an effect on the TT child reader that can be similar to that achieved by the ST.

Interestingly, it is only through illustrations that we have known that the story takes place during the pharaonic period in Egypt when seeing Iye Tue and princess Namio dressed in pharaonic costumes. It is only through them that we have a presentation of the imaginary creature: the Mermaid of the Nile. Accordingly, illustrations give the child reader information that is not available in the verbal text. Importantly, they are cultural markers of the ancient Egyptian civilization with its costumes, architecture, plants and natural settings as well.

Lexis. Through the analysis of lexis in this story, some translation problems arise. The followings are some examples.

Proper names. The proper names presented in this text are for the two main characters in this story: ilye Tue, the young shepherd and الأميرة ناميو the princess Namio.

Translation problem (18). Nord (2003, p. 3) argues that proper names are not only used to identify a specific referent, they are "culture markers" i.e. they implicitly 
indicate to which culture the character belongs. It is supposed that Youssef has selected these proper names to refer to the pharaonic civilization. Unfortunately, there is no reference in the extratextual elements or intratextual elements to the meanings of these two names. Accordingly, these names can be regarded as exonyms for the Arab child reader and English-speaking child as well. As for the Arab child reader, s/he may guess that these are real pharaonic names for children, while the English-speaking child cannot tell whether they are pharaonic or modern names for Egyptian children. This causes a translation problem.

Suggested solution. It is suggested to keep these proper names as they are presented in the translation: Iye Tue and princess Namio, then use parentheses for the first time each name is introduced to explain that they can be pharaonic names.

Translation problem (19). ناميو الأميرة princess Namio was transferred to TT as Namio only on page (8). The translator neglects the mention of princess though it is relevant here as the relationship between Iye Tue and Namio can be regarded as impossible, in Iye Tue's eyes, because she is a princess and he is an ordinary shepherd who cannot talk.

Suggested solution. It is suggested to write princess before Namio on page (8).

Common names. The Mermaid of the Nile is the imaginary creature in this fairytale. She has the body of a woman yet its lower part is that of a fish with a tail as indicated on page (16). She is a cultural marker of the Ancient Egyptian civilization. However, the mermaid is a common name yet with the capitalization of its initial letter throughout the whole story turned it to be a proper name as Nord (2003, p. 192) indicated that generic nouns can be 
turned into proper names. It is likely that the author tends to highlight the role of the mermaid in the fairytale.

One of the common names presented in this story is أعواد البوص the stems of common reed. البوص or the common reed is a kind of plant that grows on the Nile banks in Egypt. They are referred to in the story as the plant from which the flute is made. Interestingly, the way the translator rendered them into English raised many translation problems.

Translation problem (20). The translator ignored translating أعواد البوص in the following clauses on page (6) and page (22) respectively:

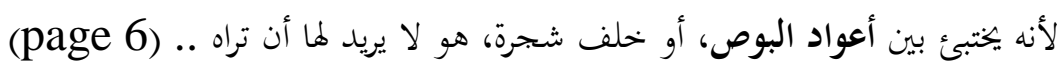

the young shepherd who hides behind a tree, for he does not want her to see him.

تخركت عروسه النيل إلى الشط، ثم اقتلعت عودا طويلا من أعواد البوص، وقطعت

الزهرة التى تعلوه ... (page 22)

The Mermaid goes to the river bank, cuts the flower off one of the long stalks and puts it in the hands of the young shepherd.

Suggested solution. It is suggested to translate the above-mentioned clause on page (6) as follows:

the young shepherd used to hide behind the stems of common reed or a tree; he does not want her to see him.

It is suggested to translate the above-mentioned clause on page (22) as follows:

The Mermaid went to the river bank then cut off one of the long stems of common reed and removed the flower off it ...

Translation problem (21). Importantly, the author explains how the Mermaid of the Nile made the flute out of a long stem of common reed: she cut off a long stem then removed the flower and the green leaves off it then cut its 
lower part then gave it to the young shepherd as a hollow stem of common reed and asked him to blow into it. Finally, that it came out to be a real flute with Iye Tue's warm tears making holes in it. However, all through these steps, the translator keeps translating the different shapes of the stem of common reed into the stalk as shown in the following extracts on pages (22), (24), (26) and (30) respectively:

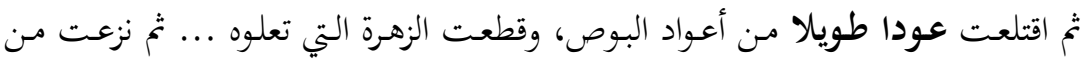

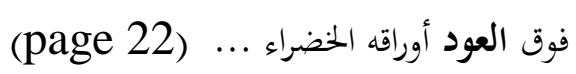

The Mermaid ... cuts the flower off one of the long stalks and puts it in the hands of the young shepherd. She then removes the leaves on the stalk ...

امتدت يد الراعى إلى تلك القطعة المجوفة من أعواد البوص، ... راح الراعي الصغير

(آى تو ) ينفخ في حافة عـود البـوص المجـوف... لتقع (الدموع السـاخنة) فوق العـود ل...

(page 24)

Iye Tue takes the stalk ... The young shepherd starts blowing into the stalk, ... They (warm tears) fall on the stalk...

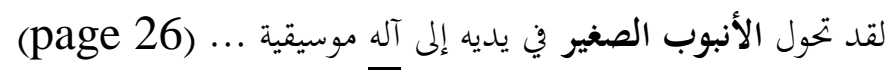

In his hands, the stalk becomes a musical instrument ...

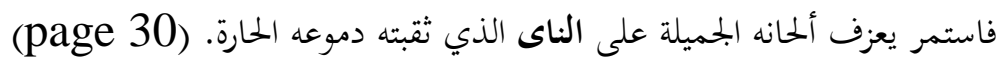

He continues playing the beautiful tunes on the stalk that is pierced by his overflowing tears.

Suggested solution. It is suggested to replace the stalk with the stem of common reed in the above-mentioned clause on page (22), with the hollow piece of the common reed on page (24), with the small tube on page (26) and finally, with the flute page (30).

Another common name that is introduced in this story is الأخرس. On page (8), the author revealed that the main male 
character of the story (Iye Tue) cannot talk. Youssef did not give clear explanation of Iye Tue's condition. However, the way the translator interpreted this case causes many translation problems.

Translation problem (22). The translator transferred the word أخرس on pages (8), (10) and (30) as follows:

$$
\text { لأن المسكين أخرس، لا يستطيع أن ينطق بكلمة واحدة. (10) (1) (page) }
$$

he is deaf and dumb. He cannot speak.

صديقا صامتًا، غير قادر على أن يتحدث إليها، أو يتكلم معها... (page 10) a silent friend who will not be able to hear or talk to her.

$$
\text { لم يكن الراعى الصغير (آى تو) قادرًا على أن ينطق أو يتكلم، لأنه أخرس، ... }
$$

(page 30)

The young shepherd, Iye Tue can not say a word anyhow since he is deaf and dumb.

It seems that the translator misinterpreted Iye Tue's condition, as the author made it clear in the extracts mentioned above that the young shepherd cannot talk but he is not deaf, or otherwise how could he play these amazing tunes on his flute?! Moreover, he could hear what the princess has said. That's why he nodded his head as if to say yes, as referred to earlier on page (32).

Suggested solution. It is suggested to translate these extracts as follows:

$$
\text { لأن المسكين أخرس، لا يستطيع أن ينطق بكلمة واحدة. (page 8) }
$$

as the poor soul is dumb; he cannot talk.

صديقا صامثًا، غير قادر على أن يتحدث إليها، أو يتكلم معها... (page 10)

a silent friend who will not be able to talk to her.

$$
\text { لم يكن الراعى الصغير (آى تو) قادرًا على أن ينطق أو يتكلم، لأنه أخرس، ... }
$$

(page 30)

The young shepherd was not able to talk because he was 


\section{dumb.}

In the same vein but in a different context, the translator misinterpreted جريد النخل on page (4) as grass instead of palm leaves and الزهور on page (32) as roses not flowers.

Sentence structure. Subordinate clauses and coordinate clauses. Youssef wrote this story in Modern Standard Arabic with no vocalization. He presented it in long sentences. They are subordinated and coordinated.

Translation problem (23). The translator has changed the pattern the author followed as she did not render some ST subordinate clauses into TT subordinates as shown in the following extract on pages (4):

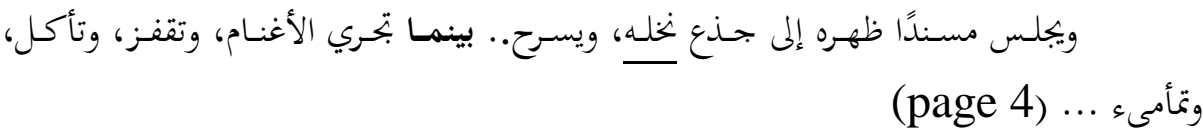

He sits, with his back leaning against the stem of a palm tree and daydream. The sheep run around, jump, eat, and bleat with joy.

She deleted the subordinate conjunctionLبينما and turned the subordinate clause into a separate sentence. This poses a translation problem.

Suggested solution. It is suggested to present the subordinate clause as it was introduced in the ST as follows: He sat with his back leaning against the stem of a palm tree and daydreamed, while the sheep ran around, jumped, ate, and bleated with joy.

In the same vein, the coordinate clause in ST was not preserved in the TT, it was rather rendered into independent sentences as shown in the following extract on page (18). فزع الراعى الصغير (آى تو) لدى رؤيه عروسه النيل تخرج إليه، ولكنه كان شجاعا، كثيرًا ما واجه الذئاب ، واستطاع أن يحمي نفسه وأغنامه منها، ل.. ( page18) 
The young shepherd Iye Tue is shocked to see the Mermaid of the Nile. She comes out to him. But he is brave. He often faced wolves and managed to protect his flock against them.

Suggested solution. It is suggested to translate this coordinate clause as follows: The young shepherd, Iye Tue, was shocked to see the Mermaid of the coming out of the water and heading towards him, but he was such a brave person who often faced wolves and managed to protect his flock against them.

Nord (2005, p. 41) argues that some source texts can be very defective and it is the translator who will recognize these defects and compensate for them. Interestingly, though the translator kept splitting clauses into simple sentences, yet it happens that she compensates for a specific defect in one of these clauses as indicated in the following extract on page (28):

ووصلت الأنغام إلى قصر الأميرة "ناميو" كانت مستلقية على مقعد وثير، ووجـدت

نفسها تقفز منه ، ... (page 28)

The tunes reach the palace. Princess Namio who is sitting on a comfortable couch jumps to the window ...

It is clear that she cut the subordinate clause into two parts with no specific reason, yet, she compensated for the absence of the relative pronoun in the ST by using who in the TT.

Suggested solution. It is suggested to translate the above-mentioned extract as follows:

The tunes have reached the palace of princess Namio who was sitting on a comfortable couch. She found herself jumping to the window ...

Types of sentences. Interestingly, the ST sentences whether jumal filliyya(h) جمل فعلية, i.e. verbal sentences whose 
initial word is a verb (Ryding, 2005, p. 58) or jumal ismiyya(h) جمل اسمية , i.e. nominal sentences that begin with a noun are presented in the past tense, while the TT sentences are presented in the present tense as shown in the following extracts:

$$
\text { كان (آى تو) يحب الأميرة (ناميو) من كل قلبه، ... (page (2) }
$$

Iye Tue is in love with Namio ....

فزع الراعى الصغير (آى تو) لدى رؤيه عروسه النيل تخرج إليه، ... (page 18)

The young shepherd Iye Tue is shocked to see the Mermaid...

Translation problem (24). The author recounts his story in the past tense as they represent past incidents, while the translator uses the present tense to introduce current incidents. The most prominent translation problem that arise from this variance is presented in the following extract on page (16):

وكان النيل يومئذ يمتلىء هذذه المخلوقات، التي يبدو نصفها الأعلى كالناس والبشر: رأس : أس

يكسوه الشعر، به عينان، وله أذنان، وأنف وفم، أما نصفها الأسفل فهو جسم سمكة وذئ وذيلها.

(page 16)

The Nile is full of those unusual creatures with a human head with hair, two eyes, two ears, a nose and a mouth but the lower part is the body of a fish with its tail.

On reading this sentence, the TT child reader will assume that the Nile is full of those creatures for the time being. Moreover, s/he will guess that on travelling to Egypt nowadays, s/he will find mermaids sitting on the Nile banks or jumping into its water. This poses a translation problem.

Suggested solution. It is suggested to translate the above-mentioned extract as follows: 
The Nile was, then, full of those unusual creatures with a human head with hair, two eyes, two ears, a nose and a mouth but the lower part was the body of a fish with its tail.

Translation problem (25). In another situation, the translator rendered the declarative statement of the ST into imperative in the TT as shown in the following extract on page (20):

إنك ترفع وجهك للسماء تشكو، ونظرة الحزن تطل من عينيك، ... (page 20)

Raise your face to the sky and convey your thoughts. There is a sad look in your eyes.

This shift from declarative to imperative statement has changed the meaning presented by the author to the ST child reader. In using the declarative sentence, the author describes the situation of Iye Tue as he was sad and complaining to Heavens. He was not giving him directions on how to convey his thoughts as the translator explained. She, thus, transferred a different meaning to the TT child reader. This raises a translation problem.

Suggested solution. It is suggested to translate this extract as follows:

You have raised your face to Heavens to complain about your situation with that sad look on your face...

Suprasegmental features. Interestingly, the author presents the elliptical words or stammering speech in Arabic by putting two dots (..) as shown in the following extracts on pages (22), (30) and (32) respectively:

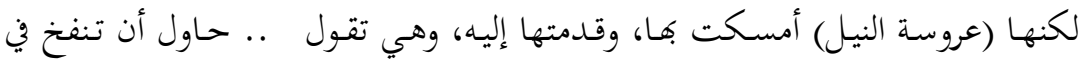

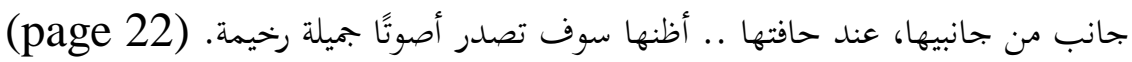
But she gives it to him and says, "Try to blow into it from one side at the edge. I think it will produce beautiful musical tunes." 
همست (الأميرة): استرح قليلا .. أنت رائع ..هذا الذى تعزفه لم يعزفه أحد قبلك، ...

(page 30)

so she whispers: "Rest for a while. You are superb. The tunes you are playing have not been played before.

فأنني أعبر لكك بصدق عن إحساسى بموسيقاك العذبة .. ألتقط أنفاسـك، ثم واصل

العزف الجميل .. أنا أحس أن كل الكائنات تسمعك: النيل .. والأشجار... والزهور .. والعصافير..

والأغنام.. والأعشاب الخضر... والكون كله، ... (page 32)

I am telling you the truth about my feeling for your charming music. Take your breath and continue playing. I fell that everything that is alive can hear you: The Nile, the trees, the roses, the birds, the sheep, the green, the whole universe.

Translation problem (26). The author uses this stammered speech to express the excitement and enthusiasm of each speaker referred to above. Unfortunately, the translator ignored all these features turning all stammered speech into ordinary sentences. This raises a translation problem.

Suggested solution. In order to adapt this suprasegmental feature of the ST to the TL pattern, it is suggested to translate the relevant extracts as follows:

لكنها (عروسة النيل) أمسكت بها، وقدمتها إليه، وهي تقول.. حاول أن تنفخ في جانب

من جانبيها، عند حافتها.. أظنها سوف تصدر أصوتًا جميلة رخيمة. (page 22) But she gave it to him and said, "... Try to blow into it from one side at the edge.

... I think it will produce beautiful musical tunes."

همست (الأميرة) استرح قليلا.. أنت رائع.. هـذا الذى تعزفه لم يعزفه أحد قبلك، ...

(page 30)

so, she whispered: "Rest for a while ... You are superb... The tunes you are playing have not been played before. 
فأنني أعبر لك بصدق عن إحساسى بموسيقاك العذبة.. ألتقط أنفاسك، ثم واصل العزف

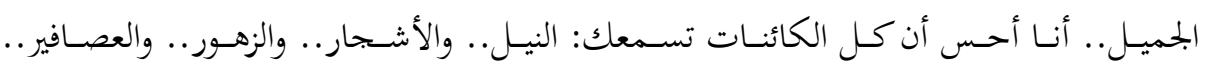

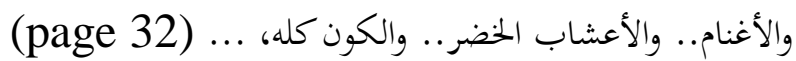

I am telling you the truth about my feeling for your charming music... Take your breath and continue playing... I feel that everything that is alive can hear you: The Nile, ... the trees, ... the flowers, ... the birds, ... the sheep, ... the green ... the whole universe.

The interdependence of intratextual factors. On analyzing the above-mentioned intratextual elements, it is clear that all these elements have intermingled to produce a specific effect on the receiver of this story. The child reader's previous expectations before reading the story, will be compared with his/her actual experiences after reading it in an attempt to figure out the expected effect at the end of the story.

Importantly, there were spelling mistakes in the ST that the translator aptly compensated for in the TT. Nevertheless, there were other spelling mistakes in the ST that were not corrected. Unfortunately, it is beyond the authority of the translator to interfere in any way with the ST. So, these mistakes are only highlighted by underlining. On the other hand, the spelling mistakes presented in the TT were corrected.

The interdependence of extratextual and intratextual factors. Importantly, by applying Nord's model in analyzing this story, it follows that examining the intratextual factors has yielded more information about translation problems than the information obtained by analyzing the extratextual elements. In view of the recursive nature of Nord's model, this can be regarded as a kind of interdependence between the extratextual and intratextual 
factors of the text. It is this interdependence that is expected to yield the prospective effect of the story.

\section{The expected effect. The effect of the relationship} between intention and text. Youssef's intention was to introduce this fairytale to the Arab child reader. Thus, he could have predicted certain effects on this child reader. However, if the sender's intention is regarded as an extratextual factor that should be analyzed to measure the expected effect of his/her text on the ST reader, the intention of the translator should be regarded as an extratextual element to be evaluated too. Importantly, the translator's intentions should be rendering the author's own text into the TC not an edited or modified version of it. In view of what was referred to in the analysis of the intratextual elements of the story, the translator tended to edit, modify and change some items of the ST when rendering them into the TT. Thus, it seems that the author's intention is different, to some extent, from that of the translator's. As a result, the effect of the TT on TC child reader is not expected to be very much similar to that of the ST child reader.

The effect of the relationship between the receiver and text-world. The text world took place at the Nile banks in the pharaonic era in ancient Egypt. It is a world that may be familiar to the Arab child readers, particularly Egyptian children. However, it is supposed to be an exotic world to the English-speaking child reader. Accordingly, it is the task of the translator to facilitate access to this alien's world (Nord's word) to TT child readers. Bearing in mind that with the wide imagination that children have, this world may be regarded as far from being strange or unfamiliar to the child reader of ST and TT.

The effect of the relationship between the receiver and style. As the author of the story, Youssef has used 
certain rhetorical instruments related to the genre of fairytales in presenting his story. These instruments are presented in clear and simple way to attain the expected effect of a fairytale on the ST child reader. Unfortunately, the translator did not present these rhetorical features of the ST the way the author introduced them. Though as a translator, she has enough knowledge of the rhetorical figures in the target culture and knows how to transmit these figures to TT child reader, yet by editing and modifying parts of the text, whether intentionally, or unintentionally, she has condoned some rhetorical figures the author devised with the aim of producing certain effects on the ST child reader. However, whatever the interpretation provided by ST and TT child readers, it is the pleasure of reading a good fairytale that will be the most important effect.

\section{Limitations of the Study}

One of the limitations of this paper is the nonspecification of the age-category of the child reader. Unfortunately, the author did not specify the age of the receivers of his story. Thereby, there is no such specification for the TT child reader as well. This may be due to commercial reasons as the child reader of any age can be the target receiver of this text.

Another limitation is the spelling mistakes in the ST that were not corrected but only underlined throughout this paper.

\section{Conclusion and Future Study}

In this paper, I have applied Christiane Nord's translation-oriented text analysis to the story of الناي الحزيين The Magic Flute written by AbdutTawaab Youssef and translated by Loubna Youssef. Through the analysis of the ST factors, it came to be that the intratextual factors have yielded more 
translation problems than the extratextual factors. The study concludes that applying Nord's functional model to this story has helped in spotting these translation problems and presenting suggested solutions to them. Thereby, it contributed in introducing a better translation.

It is recommended to present future research that focus on problems of translating children's stories from Arabic into English and vice versa. Age category of the child reader of the Arabic children's story is a significant issue that needs further investigation.

\section{References}

Coillie, J. V. \& Verschueren, W. P. (Eds.) (2006). Children's literature in translation:

Challenges and strategies. Manchester, $\mathrm{UK}$ : $\mathrm{St}$ Jerome.

Lathey, G. (Ed.). (2006). The Translation of children's literature: A reader. Clevedon,

UK: Multilingual Matters.

Munday, J. (2008). Introducing translation studies: Theories and applications. London:

Routledge.

Nord, C. (2003). Proper names in translations for children: Alice in wonderland as a case in

point. Meta, 48 (1-2), 182-196.

https://doi./org/10.7202/006966ar

Nord, C. (2005). Text analysis in translation: Theory, methodology and didactic application

of a model for translation-oriented text analysis. Amsterdam: Rodopi.

Ryding, K. C. (2005). A reference grammar of modern standard Arabic. Retrieved from

http://ebooks.rahnuma.org/religion/Arabic/Modern-

Standard-Arabic-Reference-Grammar.pdf. 
Shavit, Z. (1981). Translation of children's literature as a function of its position in the

literary polysystem. Poetics Today: Translation Theory and Intercultural Relations,

2 (4), 171-179. Retrieved from

https://trad1y2ffyl.files.wordpress.com/2010/01/childr

enslit.pdf

Tabbert, R. (2002). Approaches to the translation of children's literature: A review of critical

studies since 1960. Target, 14 (2), 303-351

https://doi./org/10.1075/target.14.2.06tab

يوسف، عبد التواب (1990). الناي الحزين. القاهرة: الهيئة المصرية العامة للكتاب. 


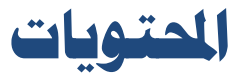

الألعاب الإلكترونية وتأثيرها على الوظائف التنفيذية للدماغ

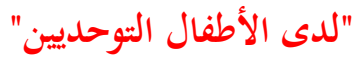

/ / حسين أحمد عبد الفتاح.....................

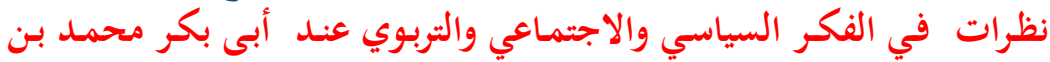

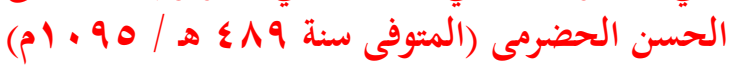

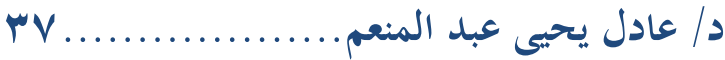

أثر السياق في دراسة البنية الاجتماعية في قصص الأنبياء سورة مريم أنموذجًا

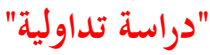

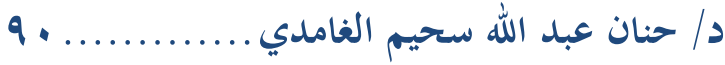

التأصيل النظري لمفهوم المسئولية الاجتماعية

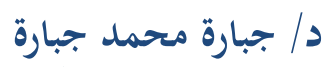

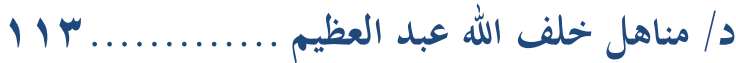

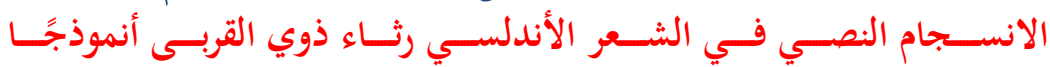

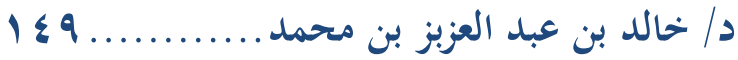

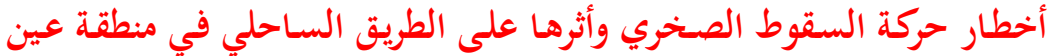

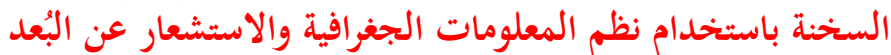

أ. أ.د/ مني عبد الرحمن يس الكيات الكيالي

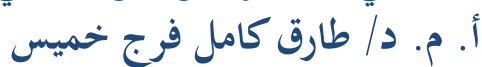

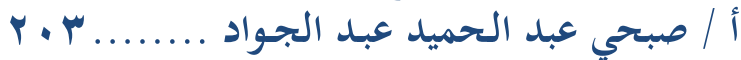

الأفعال الإنجازية في الأربعين النووية "دراسة تداولية" صبح صبديل

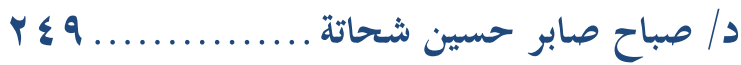

المعوقات الاجتماعية للتمكين القانوني للمرأة المصرية وسبل تجاوزها "دراسة

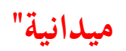

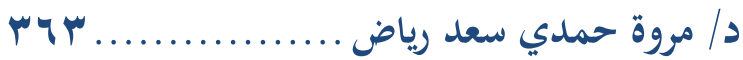

La ponctuation dans Ce que j'appelle oubli de Laurent

Mauvignier: enjeux et paradoxe

Dr. Dalia Metawe

La ponctuation dans Ce que j'appelle oubli de Laurent

Mauvignier: enjeux et paradoxe

Étude argumentative du discours daëchien

Dr. Hayame Hussien Ibrahim 
وفي بحال الدراسات التاريخية يأتي بحث الدكتور / عادل يميى عبد المنعم وعنوانه: "الفكر

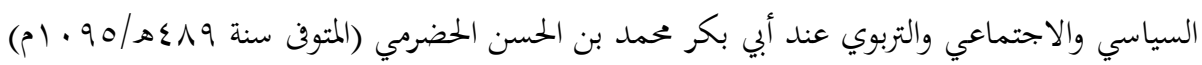

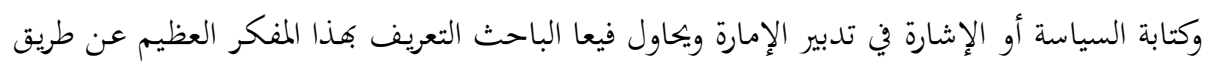
دراسة الظروف السياسية والفكرية التي عاش فيها.

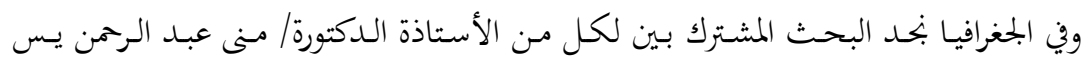

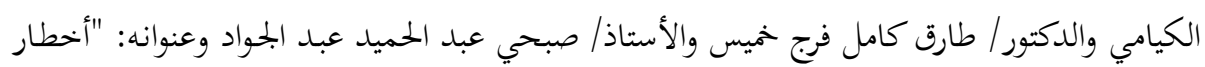

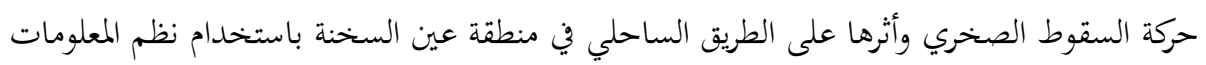

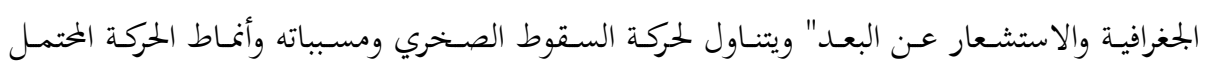

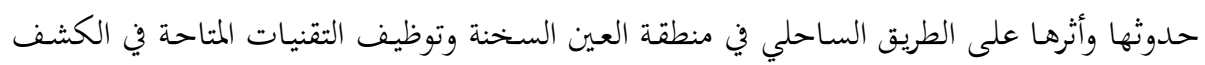
عن طبيعة منحدرات المنطقة.

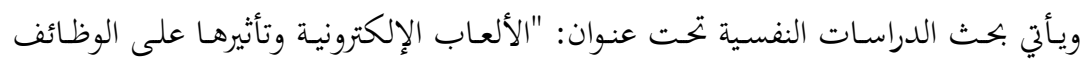

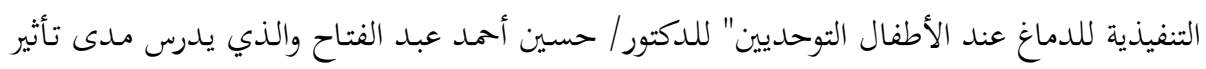

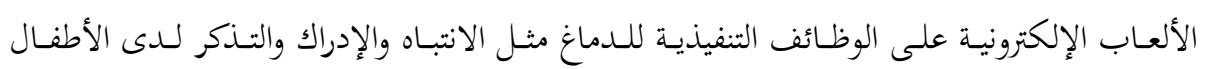
التوحديين واستخدمت الدراسة المنهج الوصفي المقارن.

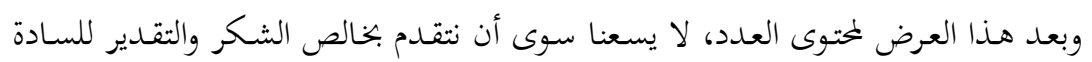

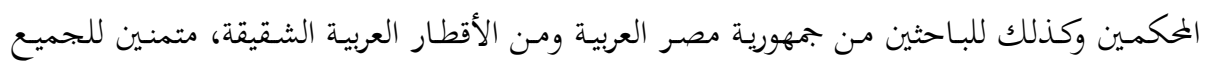
التوفيق والسداد.

نائب رئيس بحلس الإدارة

أ.د / هناء زكريا

وكيل الكلية للدراسات العليا والبحوث 


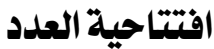

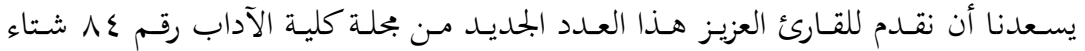

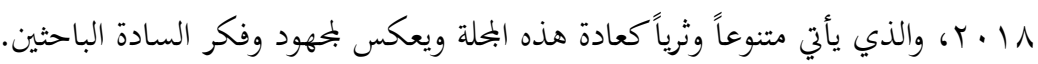

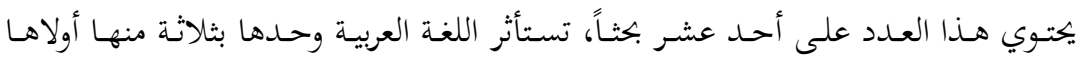

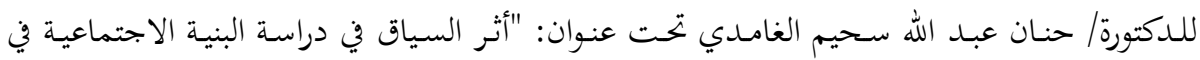

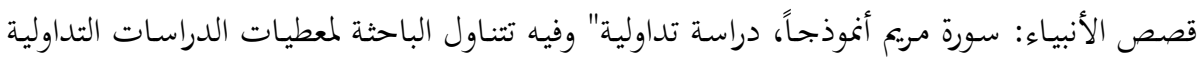

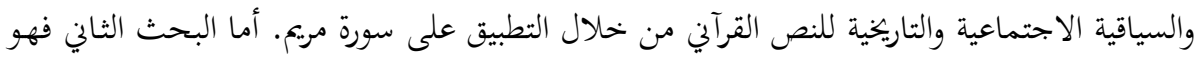

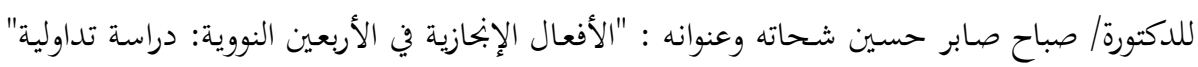

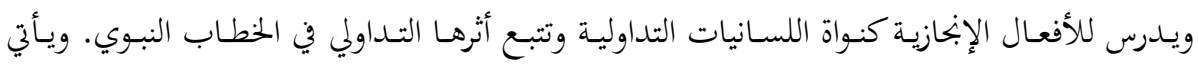

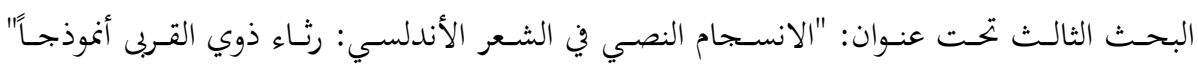

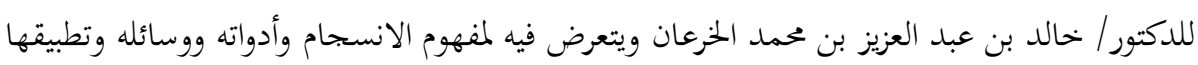

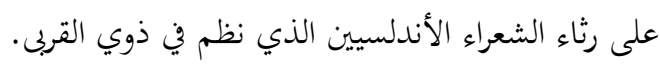

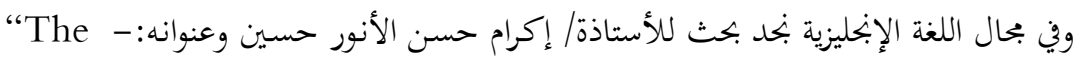
Application of Chiristiane Nord`s Translation- Oriented Text" Analysis to The Magic flute" الناي الحزين Adult Tawal- Yossefs Translated Story وللغة الفرنسية نصيب ببحثين في بحال اللغويات، أولمما للدكتورة/ هيام حسين عـامر،

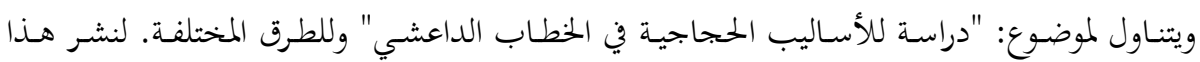

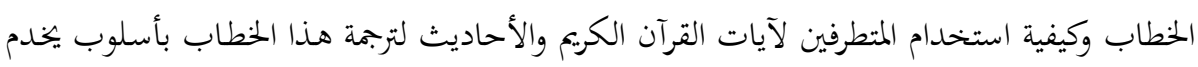

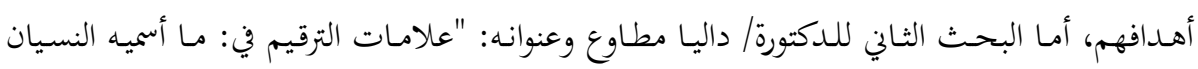
للوران موفينيه". ويتناول بالدراسة المدف من استخدام الكاتب لهذه العلامات وللعلاقة التي تربط بين الشكل النصي المميز لمذه الرواية واستخدام علامة الترقيم لإبراز اسلوب كتابة هذه الرواية.

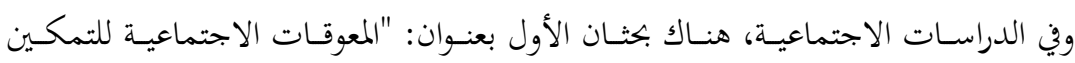

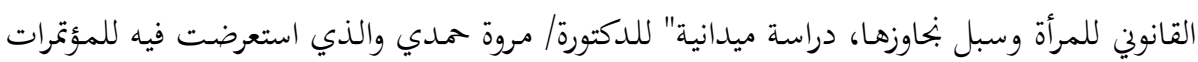

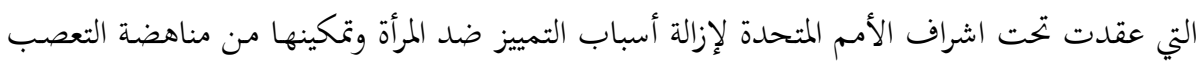

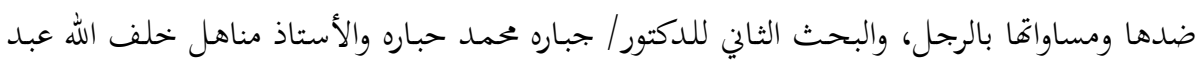

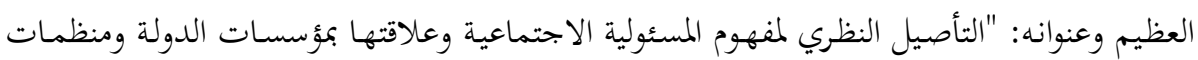
الأعمال التي تستغل موارد البحتمع لتحقيق الربح على حسابه. 


$$
\begin{aligned}
& \text { أ.د/ نازك هممد عبد اللطيف } \\
& \text { أ. د/ يسري أحمد عبد الله زيدان } \\
& \text { أ.د/ البسيوني عبد الله جاد } \\
& \text { أ.د/ هحمد ياسر شبل الخواجة }
\end{aligned}
$$




\section{أسهاء السادة الأساتذة همكي هذا العدد}

$$
\text { وفقا للترتيب الأبجدي }
$$

أ. أد/ إبراهيم عودة

أ.د/ أحمد سالم صالح

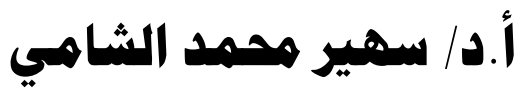

أ.د / طارق زكريا

أ.د / عبد الله هممد سليمان هنداوي

$$
\text { أ. أد/ عواطف حسين }
$$

أ.د/ قباري هممد عبده شحاتة

أ.د/ هممد علي أبو زيد

أ.د/ هممد علي هممد سلاهة

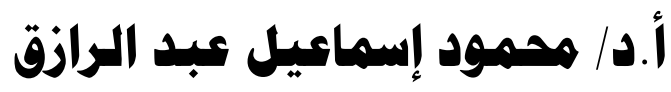

$$
\text { أ. أد/ مدحت الجيار هودوإيماعل }
$$

أ.د/ هنى أحمد عبد العزيز 



\title{
هجلة كلية \\ هبلة كلية الآداب - جاهعة الزقازيق \\ صدر العدد الأول 17 - 1917م
}

\section{هيـة التهمربر}

\author{
الأستا ذالد كتمهر

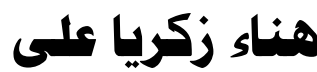 \\ وكيلالككليتللدراسات العلياوالبحوث \\ نائب رئيسمجليس الإدارة \\ الأستاذ الدكتهر \\ همند عبد الانتاح عونه \\ سكرتير التحرير
}

الأستاذ الدكتهر

تصنماد

عميد الكبليت

رئيس مجلس الإدارة

الأستاذ الدكتهر

فربدة

رئيس التحريـر

\section{مستشارو التحريز}

أ.د . أحمـــد صـــلاح الـــدين

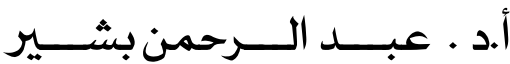

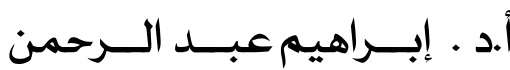

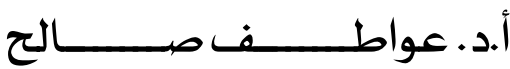

أ.د. . عثمـــان محمـــد عثمــــان

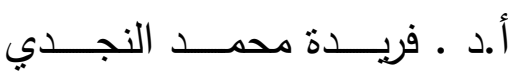

أ.د . طــارق زكـريــــا علـــي

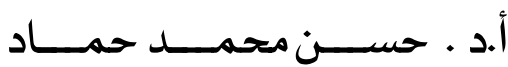

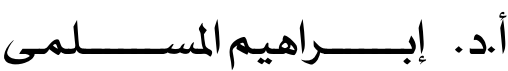


با - يرفق ملخصـان للبحث باللغتين العربيـة والإنجليزيـة على ألا يتجاوز حجم

$$
\text { الملخص صفحة واحدة. }
$$

rا - تتشر المجلة ملخصات الرسائل العلمية العربية والأجنبية.

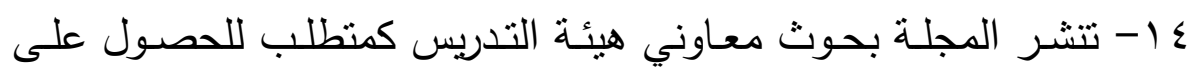

درجتي الماجستير والدكتوراه.

10- تتشر المجلة بحوث أعضـاء هيئة التدريس بدرجة أستاذ وفق القيمـة الفعلية للطباعة.

17 - توجـه جميع المكاتبـات أو الاستفسـارات الخاصـة بالنشـر إلى رئيس

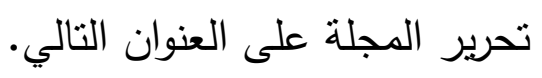

\section{كلية الآداب - جامعة الزقازيق}

\section{تليفون : oo/rrstrarl}

http://www.Arts@ Zu.edu.eg 
مجلة الكلية الآداب: فصلية- علمية- محكمة تعني بنشر الأبحاث العلمية

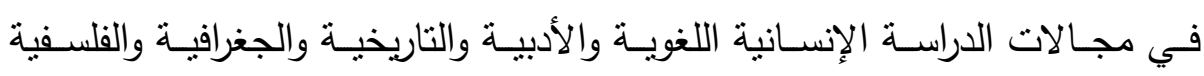

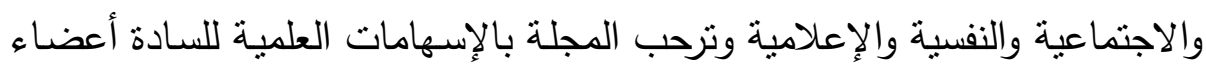
هيئة التدريس والباحثين من العالمين العربي والإسلامي لإثراء المجلة.

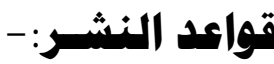

1- تقبل المجلة البحوث باللغات العربية والإنجليزية والفرنسية.

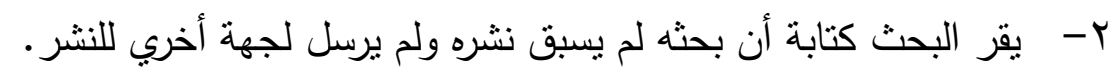

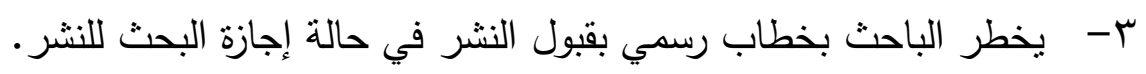

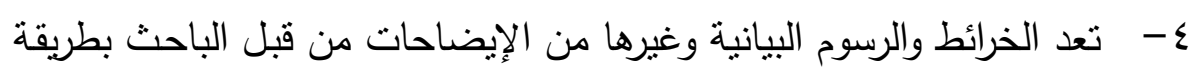

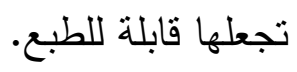

0- - تعبر البحوث المنشورة عن رأي اصحابها فقط.

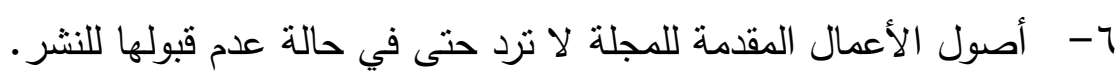

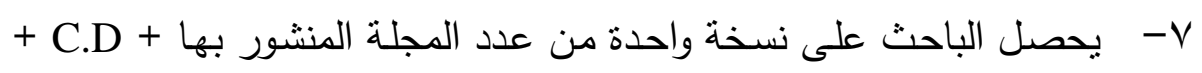

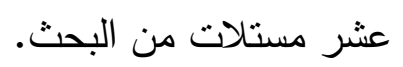

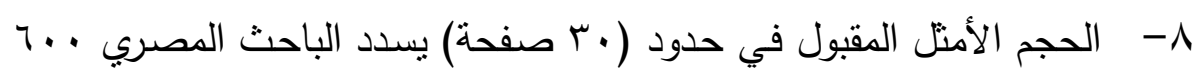

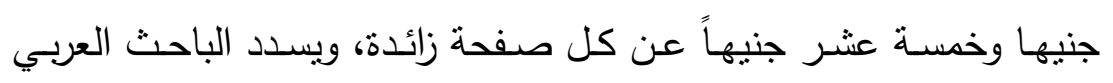
والأجنبي . . r دولار وثثلاثة دولار عن كل صفحة زائدة.

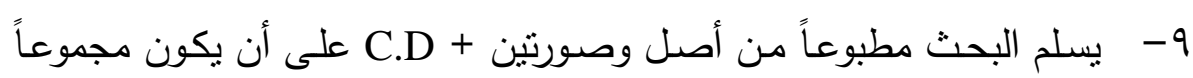
ببنط ع ا، وأن يكون مقاس الصفحة 12x19سم.

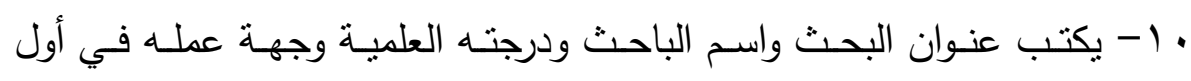
صفحة من البحث. 1 1- تكتب المراجـع والهوامش في نهايـة البحث، مـع الالتزام بالأسس العلميـة للتوثيق. 


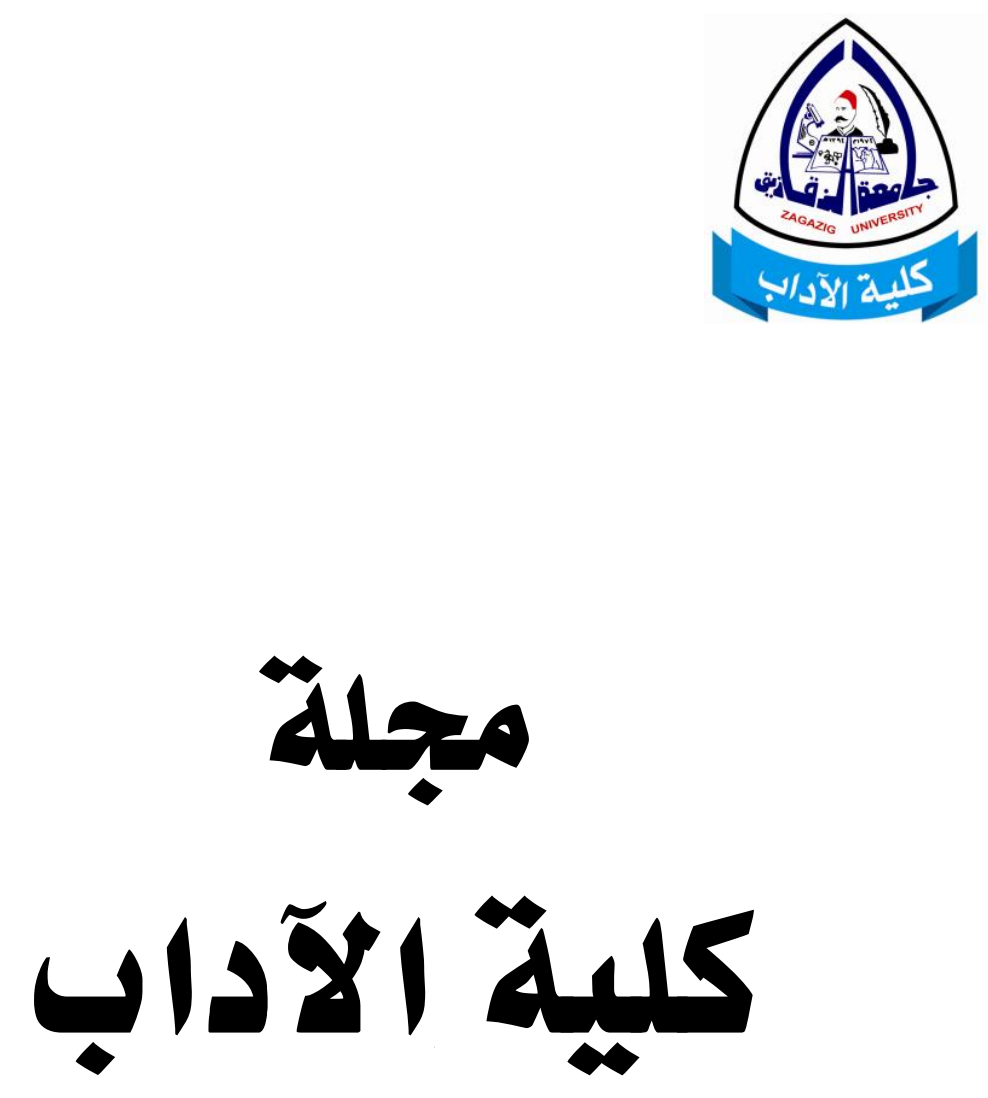

هملة علمية همكمة فصلية

شثتاs r.lv

العدد (A) 